\title{
Fish Silage in Black Bass (Micropterus Salmoides) Feed as an Alternative to Fish Meal
}

\author{
Lia Ferraz de Arruda ${ }^{1 *}$, Ricardo Borghesi ${ }^{1}$, Leandro Portz ${ }^{2}$, José Eurico Possebon Cyrino ${ }^{3}$ \\ and Marília Oetterer ${ }^{4}$ \\ ${ }^{I}$ Escola Superior de Agricultura "Luiz de Queiroz"; Piracicaba - SP - Brasil. ${ }^{2}$ Departamento de Zootecnia; Escola \\ de Agronomia; Universidade Federal da Bahia; 44380-000; Cruz das Almas - BA - Brasil. ${ }^{3}$ Departamento de \\ Zootecnia; Escola Superior de Agricultura "Luiz de Queiroz"; C. P. 9; 13418-900; Piracicaba - SP - Brasil. \\ ${ }^{4}$ Departamento de Agroindústria; Alimentos e Nutrição; Escola Superior de Agricultura "Luiz de Queiroz"; C. P.: \\ 9; 13418-900; Piracicaba-SP-Brasil
}

\begin{abstract}
The objective of this study was to use the residues of fermented sardine to elaborate the acid fish silage and its use in feed for aquaculture. Biological assay was performed by feeding largemouth bass (Micropterus salmoides) fingerlings (initial weight 22g), with extruded diets (41\% crude protein; 3,600 kcal/kg digestible energy) containing $0.0,7.5,10.0,12.5$, or $15.0 \%$ of fish silage in partial substitution to the fish meal. The feed conversion ratio and weight gain for the treatments were: 1.26 and $15.76 \mathrm{~g} ; 1.11$ and $17.07 \mathrm{~g} ; 1.19$ and $17.81 \mathrm{~g} ; 1.18$ and $19.83 \mathrm{~g} ; 1.47$ and $14.64 \mathrm{~g}$, respectively. No significant differences $(P<0.05)$ were detected among the treatments. Results indicated that it was possible to use up to $15 \%$ of acid fish silage as partial substitute for fish meal in the formulation of carnivorous fish feed.
\end{abstract}

Key words: residue, carnivorous fish, protein, fish nutrition

\section{INTRODUCTION}

Largemouth bass Micropterus salmoides (Percifomes, Centrarchidae) is found in lakes and small rivers in North America, but can also be found in Mexico and some parts of Europe. This species was introduced in Brazil in 1924 in Minas Gerais state, and was called black bass (Godoy, 1954).

Only in the state of São Paulo, where black bass was introduced and completely adapted, the practice of sport fishing has annually yielded gross values of about R\$500 million (Carvalho Filho, 1997).
As in any animal culture, in aquaculture, feed corresponds to a high percentage of the operational costs, reaching 40 to $60 \%$ of the overall. Several studies have been carried out to identify alternative protein sources which would allow for a reduction in the cost of feed (Cheng et al., 2003; Furuya and Furuya, 2006; Portz and Cyrino, 2004).

Fish waste generated by processing and commercialization stations cause serious environmental hazards. The need for the improvement in the residues system is economical and environmentally friend (Maia Junior, 1998; Ferraz de Arruda et al., 2006a).

A viable alternative would be to use the waste

Author for correspondence: liaferraz2000@yahoo.com.br 
material in the manufacture of the fish silage, since it does not require high investments. Fish silage is defined as a liquid product produced from the whole fish or parts of it, to which acids, enzymes or lactic-acid-producing bacteria are added, with the liquefaction of the mass provoked by the action of enzymes from the fish (FAO, 2007; Oetterer, 2006).

The manufacturing of silage from the comercialization of fish processing waste aiming to obtain aquaculture feed ingredient has been widely studied over the last few years. Many authors believe that, due to the similarity of this protein source with the raw material, especially amino acids, such as lysine, methionine, and cystine, silage has a high potential of use in aquaculture. Its low cost, especially when compared to fish meal is also attractive (Borghesi et al., 2006a, b; Coello et al., 2000; Fagbenro and Jauncey, 1995, 1998; Ferraz de Arruda and Oetterer, 2005; Ferraz de Arruda et al. 2006a, b; Goddard and Perret, 2005; Lessi et al., 1989; Ristic et al., 2002; Vidotti et al., 2003).

The objective of this study was to use the waste of fermented sardines from a fish industry in Ubatuba-SP-Brazil.

\section{MATERIAL AND METHODS}

For the elaboration of silage, waste from the cleaning or finishing of fish products from an anchovy-processing plant in Ubatuba, SP, containing about $30 \%$ salt, was used. Silage was produced from $30 \mathrm{~kg}$ of waste, which was triturated in a Super Cutter Sire grinder and added to an acid mixture (sulphuric acid and formic acid at the rate of 3:1) for the adjustment of the $\mathrm{pH}$ at 4.0. The $\mathrm{pH}$ of the silage was monitored and controlled with the help of a digital potentiometer and the addition of acid mixture.

The chemical analyses were carried out to determine the moisture $(45.46 \%)$, crude protein (15.52\%), ash (23.78\%), lipids (4.48\%), salt $(16.89 \%)$ and energy $\left(2,500 \mathrm{kcal} \mathrm{kg}^{-1}\right)$ of the acid silage, in accordance with the method described by AOAC (1990).

In order to define the treatments, five rations were formulated where the silage inclusion levels varied in $0 ; 7.5 ; 10 ; 12.5$; and $15 \%$ through a linear programming application for the formulation of minimum-cost rations (Table 1).
The levels of digestible energy $\left(3,600 \mathrm{kcal} \mathrm{kg}^{-1}\right)$ and protein $(41 \%)$ were fixed according Portz (2001). The ration's level of starch was fixed at $12 \%$ in order to allow the expansion of the material during the extrusion process (Kearns, 1999).

The ingredients used to the elaboration of the rations were ground in a $1.5 \mathrm{~mm}$ sieve. The rations were processed in the form of extruded $3.5 \pm 0.5$ $\mathrm{mm}$ grains, in an experimental Imbramaq MX-50 extruder with extrusion capacity of $50 \mathrm{~kg} \mathrm{~h}^{-1}$.

After extrusion, each ration was submitted to pulverization with vegetable oil through a pressure pistol, at an amount calculated for the balance of the energy content. Rations were dried in a forced air oven at $45^{\circ} \mathrm{C}$ for $24 \mathrm{~h}$. Rations were stored at $7^{\circ} \mathrm{C}$. A sample from each ration was taken and submitted to the bromatological analysis as a standard for quality control (Table 1).

One hundred and eighty black bass $(22 \pm 0.05 \mathrm{~g})$, conditioned to accept artificial feed (Lovshin and Rushing, 1989), were ramdomly stocked in 60-L cages (15 cages; 12 fish per cage), placed in $1 \mathrm{~m}^{3}$ plastic tanks ( 3 cages $\operatorname{tank}^{-1}$ ) in an totally randomized experimental design $(n=3)$, housed in a laboratory supplied by a closed water recirculating system, with aeration and oxygenation systems. Water temperature was maintained at $24 \pm 1{ }^{\circ} \mathrm{C}$ by automatic electric heater. Illumination in the laboratory was provided by eight halogen (daylight) bulbs and maintained by electric timer at $14 \mathrm{~L}: 10 \mathrm{D}$ as recommended by Heinen (1998).

Prior to the study, ten fish were submitted to a benzocaine overdose, ground and immediately frozen in a container immersed into liquid nitrogen, and stored in a freezer $\left(-80^{\circ} \mathrm{C}\right)$ for later analysis of initial carcass composition.

Fishes were fed until apparent satiation twice a day (7 a.m. and 5 p.m.) for a period of 66 days. Feed consumption was measured by weighing the containers of each diet every three days in a semianalytical scale of 0.001 -g precision.

At the end of the experrimental period, fishes were fasted for $24 \mathrm{~h}$, anaesthetized $(0.5 \mathrm{~g}$ benzocaine 10 $\mathrm{L}^{-1}$ ) and weighed. Randomized samples of four fishes were taken from each replicate, killed by overdose of benzocaine ( $\left.3 \mathrm{~g} 10-\mathrm{L}^{-1}\right)$, minced and stored as previously described for further analysis of the final carcass composition. 
Table 1 - Chemical composition and analyses of the ration.

\begin{tabular}{|c|c|c|c|c|c|}
\hline & \multicolumn{4}{|c|}{ Rations } & \multirow[b]{2}{*}{ T5 } \\
\hline & T1 & $\mathbf{T 2}$ & T3 & T4 & \\
\hline \multicolumn{6}{|l|}{ Ingredients(\%) } \\
\hline Fish meal & 32.5 & 35.0 & 37.5 & 40.0 & 36.5 \\
\hline Soy meal & 31.0 & 29.4 & 24.7 & 25.4 & 34.5 \\
\hline Corn & 0.0 & 0.0 & 0.0 & 5.0 & 2.9 \\
\hline Wheat flour & 15.0 & 15.0 & 15.0 & 15.0 & 15.0 \\
\hline Soy oil & 5.9 & 7.5 & 11.2 & 6.4 & 10.6 \\
\hline Silage & 15.0 & 12.5 & 10.0 & 7.5 & 0.0 \\
\hline Premix & 0.5 & 0.5 & 0.5 & 0.5 & 0.5 \\
\hline Vitamin C & 0.1 & 0.1 & 0.1 & 0.1 & 0.1 \\
\hline \multicolumn{6}{|l|}{ Composition* } \\
\hline Moisture & 13.35 & 13.19 & 12.81 & 10.65 & 9.54 \\
\hline Crude protein & 37.78 & 37.44 & 37.27 & 37.41 & 37.59 \\
\hline Ash & 16.46 & 16.05 & 15.94 & 15.23 & 13.48 \\
\hline Lipids & 32.41 & 33.32 & 33.98 & 36.23 & 39.44 \\
\hline
\end{tabular}

Where: $\mathrm{T} 1=15 \%$ of silage; $\mathrm{T} 2=12.5 \%$ of silage; $\mathrm{T} 3=10 \%$ of silage; $\mathrm{T} 4=7.5 \%$ of silage and $\mathrm{T} 5=0 \%$ of silage.

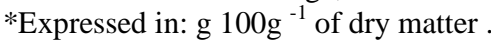

The performance and body composition results were submitted to analysis of variance (ANOVA) and Tukey's test for mean comparison (SAS 1985). The performance parameters were evaluated as recommended by Erfanullah and Jafri (1999), Hung et al. (1989), Moore et al. (1988): Weight gain - WG $(\%)=($ final body weight initial body weight / initial body weight) x 100; Feed conversion $-\mathrm{FC}(\mathrm{kg} / \mathrm{kg})=$ food intake $/$ weight gain; Protein retention $-\mathrm{PR}(\%)=[($ final body weight $\mathrm{x}$ final body protein - initial body weight $\mathrm{x}$ initial body protein) / total protein intake] $\mathrm{x}$ 100; Protein efficiency rate PER $(\%)=$ weight gain $(\mathrm{g}) /$ protein in the diet $(\mathrm{g})$; Specific growth rate SGR $(\%)=100$ [(ln final body weight $-\ln$ initial body weight) / experimental days].

\section{RESULTS AND DISCUSSION}

As discussed by Ottati et al. (1990), the silage production process is simple, practical and economical, not requiring expensive equipment and procedures, such as those used in the production of fish meal. According to Espíndola Filho (1999), for a decrease in the silage production costs, the use of sulphuric and formic acids (3:1) as propionic substitutes is recommended.

A slight decrease in the protein fraction in the period analyzed was also possible, which was $38.12 \%$ for silages produced with fresh waste and
$39.06 \%$ for silage produced with waste from the fermentation process, to 35.64 and $36.32 \%$, respectively. These decreases indicated the occurrence of protein hydrolysis (FAO, 2007; Oetterer, 2006).

The highest nutritive value of silage is directly related to the storage time (Ferraz de Arruda et al, 2006a; Oetterer, 2006; Raa and Njaa, 1989).

Thus, considering only the total protein analyzed, it would be better to use the silage immediately after its preparation. The mischaracterization observed in the silage in the visual examination, with the formation of a brownish pasty mass, was in accordance with Morales-Ulloa and Oetterer (1997) and Espíndola Filho (1999).

The final $\mathrm{pH}$ value of silage produced in this study was 4.12 which was in accordance with Oetterer (2002), who prescribed up to 4.5 , an ideal $\mathrm{pH}$ to guarantee conservation.

Among the performance parameters (weight gain percentage - WG; feed conversion - FC, protein retention - PR), there was no statistical difference $(P>0.05)$ among the treatments (Table 2).

For the moisture, ash, and lipids values, no significant variation $(P>0.05)$ was observed, which was an important factor for a possible comparison parameter in posterior fish processing. There were no significant differences $(P<0.05)$ among the treatments in weight gain (WG), Food conversion (FC), Protein efficiency ratio (PER) e specific growth rate (SGR). 
Table2 - Performance and composition parameters of the carcass.

\begin{tabular}{|c|c|c|c|c|c|c|}
\hline \multicolumn{7}{|c|}{ Experimental diets } \\
\hline & T1 & T2 & T3 & T4 & T5 & $\mathrm{CV}$ \\
\hline WG $(\%)$ & $14.6^{\mathrm{a}^{*}}$ & $19.8^{\mathrm{a}}$ & $17.8^{\mathrm{a}}$ & $17.0^{\mathrm{a}}$ & $15.7^{\mathrm{a}}$ & 22.5 \\
\hline $\mathrm{FC}(\mathrm{g} / \mathrm{g})$ & $1.4^{\mathrm{a}}$ & $1.1^{\mathrm{a}}$ & $1.1^{\mathrm{a}}$ & $1.1^{\mathrm{a}}$ & $1.2^{\mathrm{a}}$ & 11.8 \\
\hline $\operatorname{SGR}(\%)$ & $0.7^{\mathrm{a}}$ & $0.9^{\mathrm{a}}$ & $0.8^{\mathrm{a}}$ & $0.8^{\mathrm{a}}$ & $0.7^{\mathrm{a}}$ & 23.2 \\
\hline PER $(\%)$ & $3.5^{\mathrm{a}}$ & $4.8^{\mathrm{a}}$ & $4.3^{\mathrm{a}}$ & $4.1^{\mathrm{a}}$ & $3.8^{\mathrm{a}}$ & 22.5 \\
\hline \multicolumn{7}{|c|}{ Carcass composition (\%) } \\
\hline Moisture & $78.1^{\mathrm{a}}$ & $77.1^{\mathrm{a}}$ & $76.6^{\mathrm{a}}$ & $77.4^{\mathrm{a}}$ & $76.3^{\mathrm{a}}$ & 4.7 \\
\hline Protein & $15.5^{\mathrm{a}}$ & $16.7^{\mathrm{ab}}$ & $14.5^{b}$ & $14.2^{\mathrm{b}}$ & $14.9^{\mathrm{ab}}$ & 6.5 \\
\hline Ash & $4.1^{\mathrm{a}}$ & $4.0^{\mathrm{a}}$ & $3.8^{\mathrm{a}}$ & $3.7^{\mathrm{a}}$ & $3.6^{\mathrm{a}}$ & 8.2 \\
\hline Lipids & $2.7^{\mathrm{a}}$ & $3.1^{\mathrm{a}}$ & $3.4^{\mathrm{a}}$ & $3.5^{\mathrm{a}}$ & $3.8^{\mathrm{a}}$ & 14.0 \\
\hline \multicolumn{7}{|c|}{ Nutrient retention $(\%)$} \\
\hline PR & & $29.0^{\mathrm{a}}$ & $36.6^{\mathrm{a}}$ & $37.7^{\mathrm{a}}$ & $33.6^{\mathrm{a}}$ & 17.2 \\
\hline
\end{tabular}

Where: $\mathrm{T} 1=15 \%$ of silage; $\mathrm{T} 2=12.5 \%$ of silage; $\mathrm{T} 3=10 \%$ of silage; $\mathrm{T} 4=7.5 \%$ of silage and $\mathrm{T} 5=0 \%$ of silage.

*Values followed by the same superscript do not differ $P<0.05$.

The results of weight gain were lower than the results obtained by Portz (2001) for the black bass (between 29.20 and $56.87 \mathrm{~g}$ ), who studied the replacement of fish meal by different by-products (animal and vegetal). The better result obtained by Portz (2001) could be attributed to the diets, which were formulated based on ideal protein concept relating the specific requirements of the essential amino acids for a perfect fish growth, instead of crude protein used in this study that only considered the protein content and, thus, could present unbalance in amino acids, and consequently, low growth and feed efficiency.

Weight gain values also were lower than that obtained with acid fish silage (AFS) by Heras et al. (1994) (42-54 g) and Hardy et al. (1984) working with Atlantic salmon (Salmo salar) (37.5-47.9 g) and rainbow trout (Onchorynchus mykiss), respectively. Food conversion ratios values were better than that obtained by Fagbenro and Jauncey (1995) (1.45-1.59 g) working with catfish (Clarias gariepinus) fed with fermented fish silage co-dried with many by-products (animal and vegetal), Hardy et al. (1984) (1.50$1.62 \mathrm{~g})$ and Stone et al. (1989) (1.33-1.71 g) with rainbow trout (Onchorynchus mykiss) and Jackson et al. (1984) (1.55-1.74 g) with Atlantic salmon (Salmo salar), all of these working with AFS.

Specific growth rates in this study (0.76-0.92) were lower than that reported by Vidotti (2001) for the pacu (Piaractus mesopotamicus) fed with diets containing different kinds of co-dried fish silage and by Fagbenro and Jauncey (1995) with catfish. The values of protein efficiency ratios (3.57-4.8\%) were higher than that obtained by Vidotti (2001)
$(1.99-2.61 \%)$ to the pacu (Piaractus mesopotamicus), Stone et al. (1989) (1.28-1.73\%), Hardy et al. (1984) (1.61-1.69\%) to the rainbow trout (Onchorynchus mykiss) and Heras et al. (1994) (1.55-1.57\%) to the Atlantic salmon (Salmo salar). All of these authors used fish silage as a principal protein source. Fishes are the largest existing vertebrate group and have different dietary habits and specific and differential nutritional requirements. Variability in the results of the parameters studied in the different experiments mentioned could be attributed to the need to consider the specific quantitative and qualitative requirements for the species and development stage during the diets formulation. Besides these factors, silage standardization is necessary to be used as a protein source, delimitating the ideal hydrolysis time in which there is no loss of the protein quality loss, and maximum of in-vivo digestibility.

There are few works studying the use of fish silage on fish performance experiments. Larger studies must be developed for the evaluation of the ideal quantity of silage in the elaboration of fish rations. The bioconversion of the wasted material and its consequent use can bring economical advantages for the industries, besides solving a great problem with the elimination of waste, which is a polluting, hardly disposable material as well as for the decrease in feed costs for the carnivorous fish.

Estimating that about $50 \%$ of the production cost in aquaculture is due to the feed, a reduction in the cost of feed must result a decrease in the price of fish and facilitate its purchase by the consumer. 


\section{CONCLUSION}

It is possible to use up to $15 \%$ AFS in black bass feed with no harm for the performance parameters of this species.

\section{ACKNOWLEDGEMENT}

Authors thank Foundation for Research Support of the State of São Paulo (FAPESP) for funding this research.

\section{RESUMO}

O objetivo desta pesquisa foi estudar a utilização de resíduos de sardinha fermentada para elaboração de silagem química e sua utilização em rações para aquacultura. Foi realizado ensaio de ganho de peso utilizando juvenis de "black bass" (Micropterus salmoides), com peso inicial de 22 gramas, onde utilizou-se rações extrusadas $(41 \%$ de proteína bruta, $3.600 \mathrm{kcal} / \mathrm{kg}$ de energia digestível) contendo 0,$0 ; 7,5 ; 10,0 ; 12,5 ; 15,0 \%$ de silagem em substituição à farinha de peixe. A composição química da silagem de pescado (matéria seca) apresentou valores de proteína bruta

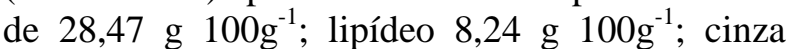

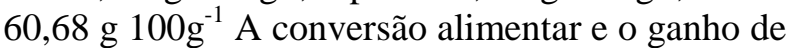
peso para os tratamentos foram, respectivamente: 1,26 e $15,76 \mathrm{~g} ; 1,11$ e $17,07 \mathrm{~g} ; 1,19$ e $17,81 \mathrm{~g} ; 1,18$ e $19,83 \mathrm{~g} ; 1,47$ e $14,64 \mathrm{~g}$. Nenhuma diferença significativa $(P<0,05)$ foi encontrada entre os tratamentos. Os resultados indicam a possibilidade da utilização de até $15 \%$ de silagem na substituição da farinha de peixe, em rações para peixes carnívoros.

\section{REFERENCES}

Association of Official Analytical Chemists. (1990), Official Methods Of Analysis. 14.Ed. Washington: Aoac. 1141p.

Borghesi, R. ; Ferraz de Arruda, L.; Portz, L.; Oetterer. M. (2006a), Coeficiente de digestibilidade aparente da energia e nutrientes das silagens ácida, biológica e enzimática pela tilápia do nilo. In: Congresso Latinoamericano de Alimentação Animal, 2., São Paulo, 2006. Anais. São Paulo: Cbna-Amena, $(\mathrm{Cd}-$ Rom).
Borghesi, R. ; Ferraz De Arruda, L.; Portz, L.; Oetterer. M. (2006b), Coeficiente de digestibilidade aparente para proteína e aminoácidos das silagens ácida, biológica e enzimática pela tilápia do nilo. In: Congresso Latinoamericano de Alimentação Animal, 2., São Paulo, 2006. Anais. São Paulo: Cbna-Amena, (Cd-Rom).

Carvalho Filho. (1997), Ah, vida dura: a febre dos pesque-pagues. Panorama da Aquicultura, 39, 7, p.20-21.

Coello, N.; Brito, L.; Nonus, M. (2000), Biosynthesis of L-Lysine By Corynebacterium Glutamicum Grown on Fish Silage. Bioresource Technology, 73, p.221$225,2000$.

Cheng, Z.J.; Hardy, R.W.; Usry, J.L. (2003), Effects Of Lysine Supplementation In Plant Protein-Based Diets on the Performance of Rainbow Trout (Oncorhynchus mykiss) and Apparent Digestibility Coefficients of Nutrients. Aquaculture, 215, 255-265.

Espíndola Filho, A. (1999), Aproveitamento do resíduo sólido de peixe, camarão e bivalves como ingrediente de ração para aqüicultura. São Paulo: Universidade Mackenzie, 224p. (Doutorado).

Erfanullah, A.; Jafri, A.K. (1999), Growth, feed conversion, body composition and nutrient retention efficiencies in fingerling catfish, Heteropneustes fossilis (Bloch), fed different sources of dietary carbohydrate. Aquaculture Research, 30, 43-49.

Fagbenro, O.; Jauncey, K. (1995), Growth and protein utilization by juvenile catfish (clarias gariepinus) fed dry diets containing co-dried lactic-acid-fermented fish-silage and protein feedstuffs. Bioresource Technology, 51, 29-35.

Fagbenro, O.; Jauncey, K. (1998), Physical and nutritional properties of moist fermented fish silage pellets as a protein supplement for tilapia (Oreochromis niloticus). Animal Feed Science Technology, 71, 11-18.

FAO. (2007), Animal Feed Resources Information System. http://www.fao.org. (20 Mar. 2007)

Ferraz de Arruda, L.; Oetterer, M. (2005), Silagem Ácida- uma tecnologia alternativa para aproveitamento do resíduo o processamento do pescado. Revista Aquicultura and Pesca, 14 (1), 3033.

Ferraz de Arruda, L.; Borghesi, R.; Brum, A. S.; D'arce, M; Oetterer, M. (2006a), Ácidos graxos em silagem de resíduos do processamento da tilápia do nilo. In: Congresso Latinoamericano de Alimentação Animal, 2., São Paulo, 2006. Anais. São Paulo: Cbna-Amena, (Cd-Rom).

Ferraz de Arruda, L.; Borghesi, R.; Brum, A. S.; D'arce, M; Oetterer, M. (2006b), Óleo de silagem de tilápia do nilo (oreochromis niloticus) extraido pelos métodos de centrifugação, soxhlet e Bligh and Dyer. in: simpósio de controle do pescado, 2, São Vicente, 2006. Anais. São Paulo: Instituto de Pesca. (CdRom). 
Furuya, W. M; Furuya, V. R. B. (2006), Exigências de aminoácidos para peixes tropicais. In: Congresso Latinoamericano de Alimentação Animal, 2., São Paulo, 2006. Anais. São Paulo: Cbna-Amena. (CdRom).

Jackson, A. J.; Kerr, A. K.; Bullock, A. M. (1984), Fish silage as a dietary ingredient for salmon. II. Preliminary growth findings and nutritional pathology. Aquaculture, .40, 283-291.

Goddard, J. S.; Perret, J. S. M. (2005), Co-drying fish silage for use in aquafeeds. Animal Feed Science And Technology, 118, 337-342.

Godoy, M. P. (1954), Observações sobre a adaptação do "black bass" (Micropterus salmoides) em Pirassununga, Estado de São Paulo. Revista Brasileira de Biologia, 14 (12), 32-38.

Hardy, R. W.; Shearer, K. D.; Spinelli, J. (1984), The nutritional properties of co-dried fish silage in rainbow trout (Salmo gairdinieri) dry diets. Aquaculture. 38, 35-44.

Heinen, J. M. (1998), Light control for fish tanks. Progressive Fish Culturist, 60, 323-330.

Heras, H.; Mcleod, C. A.; Ackman, R. G (1994). Atlantic dogfish silage vs. herring silage in diets for atlantic salmon (Salmo salar): growth and sensory evaluation of fillets. Aquaculture, 125, 93-106.

Hung, S. O.; Fynn Aikins, F. K.; Lutes, P. B.; Xu, R. (1989); Abilty of juvenile white sturgeon (Acipenser transmontarus) to utilize different carbohydrate source. Journal of Nutrition, 119, 727-733.

Kearns, J. P. (1999), Ingredient consideration, preparation of feeds, selection of extrusion equipment and automatic controls for extrusion of pet and aquatic feeds. In: Chang, Y. K.; Wang, S.S. Advances In Extrusion Technology. Lancaster: Technomic Publishing Co., p.97-106.

Lessi, E; Ximenes Carneiro, A. R.; Lupin, H. M. (1989) Obtención de ensilado biológico. in: consulta de expertos sobre tecnologia de productos pesqueros en america latina, 2. Montevideo, 1989. Roma: FAO. 8p.

Lovshin, L. L.; Rushing, J. H. (1989); acceptance by largemouth bass fingerlings of pelleted feed with a gustatory additive. The progressive of fish culturist, 51, 73-78.

Maia Júnior, W. M. (1998), Adequação do processamento de silagens de resíduos de tilápia, caracterização dos lipídios e da fração seca em pó. João Pessoa: Universidade Federal da Paraíba, 116p. (Mestrado).

Moore, B. J.; Hung, S. S. O.; Medrano, J. F. (1988), Protein requirements of hatchery-produced juvenile white surgeon (Acipenser transmontanus), Aquaculture, 71, 235-245.

Morales-Ulloa, D. F.; Oetterer, M. (1997), Composição em aminoácidos de silagens químicas, biológicas e enzimáticas preparadas com resíduos de sardinha. Ciência e Tecnologia de Alimentos, 17 (3), p.252258.
Ottati, M.; Gutierrez, M.; Bello, R (1990), Estudio sobre la elaboración de ensilado microbiano a partir de pescado proveniente de especies subutilizadas. Arcchivos Latinoamericanos de Nutrición, 40 (3), 408-425.

Oetterer, M. (2002), Industrialização do pescado Cultivado. Guaíba: Agropecuária, 200p.

Oetterer. M. (2006), Proteínas do pescadoprocessamento com intervenção protéica. In: Oetterer, M.; Regitano D’Arce, M.A.; Spoto, M.H.F. Fundamentos de Ciência e Tecnologia de Alimentos. Barueri: Manole, p. 99-134.

Portz, L. (2001), Utilização de diferentes fontes protéicas em dietas formuladas pelo conceito de proteína ideal para o "black bass" (Micropterus salmoides). Piracicaba: USP/ESALQ, $111 \mathrm{p}$. (Doutorado).

Portz, L.; Cyrino, J. E. P. (2004), Digestibility of nutrients and aminoacids of different protein sources in practical diets by lagermoth bass Micropterus salmoides (Lacepéde, 1802). Aquaculture Research, 36, p.19.

Raa, M. E. J.; Njaa, L. R. (1989), Nutritional value of stored fish silage as a protein source for young rats. Journal of the Science Food and Agriculture, 49, 259-270.

Ristic, M.D.; Filipovic, S.S.; Sakac, M.L.J. (2002), Liquid protein feedstuffs from freshwater fish byproducts as a component of animal feed. Romanian Biotechnological Letters, 7 (3), 729-736.

SAS Institute. (1985), SAS User's Guide: Statistics. 5.Ed. Cary, 365p.

Stone, F. E.; Hardy, R. W.; Shearer, K. D.; et al., (1989) Utilization of fish silage by rainbow trout (Salmo gairdineri). Aquaculture, 76, 109-118.

Vidotti, R. M. (2001), Produção e utilização de silagens de peixe na nutrição do pacu (Piaractus mesopotamicus). Jaboticabal: UNESP/CAUNESP. 65p. (Doutorado).

Vidotti, R. M.; Viegas, E. M. M.; Carneiro, D. J. (2003) Amino acid composition of processed fish silage using diferent raw materials. Animal Feed Science. and Technology, 105, 199-204.

Received: April 10, 2007; Revised: November 28, 2007; Accepted: October 27, 2008. 